25 Antiplatelet Trialists' Collaboration. Collaborative overview of randomised trials of antiplatelet therapy. Prevention of death, myocardial infarction, and stroke by prolonged antiplatelet therapy in various categories of patients. BMJ 1994; 308: 81-106.

26 Lip GY, Edwards SJ. Stroke prevention with aspirin, warfarin and ximelagatran in patients with non-valvular atrial fibrillation: a systematic review and meta-analysis. Thromb Res 2006; 118: 321-33.

27 Deyo RA, Cherkin DC, Ciol MA. Adapting a clinical comorbidity index for use with ICD-9-CM administrative databases. J Clin Epidemiol 1992; 45: 613-9

28 Bradford DW, Kim MM, Braxton LE, Marx CE, Butterfield M, Elbogen EB. Access to medical care among persons with psychotic and major affective disorders. Psychiatr Serv 2008; 59: 847-52.

29 Kilbourne AM, Welsh D, McCarthy JF, Post EP, Blow FC. Quality of care for cardiovascular disease-related conditions in patients with and without mental disorders. J Gen Intern Med 2008; 23: 1628-33.

30 Hippisley-Cox J, Parker C, Coupland C, Vinogradova Y. Inequalities in the primary care of patients with coronary heart disease and serious mental health problems: a cross-sectional study. Heart 2007; 93: 1256-62.

31 Roberts L, Roalfe A, Wilson S, Lester $\mathrm{H}$. Physical health care of patients with schizophrenia in primary care: a comparative study. Fam Pract 2007; 24: 34-40.

32 Weiss AP, Henderson DC, Weilburg JB, Goff DC, Meigs JB, Cagliero E, et al. Treatment of cardiac risk factors among patients with schizophrenia and diabetes. Psychiatr Serv 2006; 57: 1145-52.

33 Paszat LF, Mackillop WJ, Groome PA, Zhang-Salomons J, Schulze K, Holowaty E. Radiotherapy for breast cancer in Ontario: rate variation associated with region, age and income. Clin Invest Med 1998; 21: 125-34.

34 Carney CP, Woolson RF, Jones L, Noyes R Jr, Doebbeling BN. Occurrence of cancer among people with mental health claims in an insured population. Psychosom Med. 2004; 66: 735-43.
35 Lawrence D, Jablensky AV, Holman CD, Threlfall TJ, Fuller SA. Excess cancer mortality in Western Australian psychiatric patients due to higher case fatality rates. Acta Psychiatrica Scand 2000; 101: 382-8.

36 Kisely S, Sadek J, MacKenzie A, Lawrence D, Campbell LA. Excess cancer mortality in psychiatric patients. Can J Psychiatry 2008; 53: 753-61

37 Rieckmann N, Kronish IM, Haas D, Gerin W, Chaplin WF, Burg MM, et al. Persistent depressive symptoms lower aspirin adherence after acute coronary syndromes. Am Heart J 2006; 152: 922-7.

38 Shander D. Cardiovascular procedures in patients with mental disorders. JAMA 2000; 283: 3198-9.

39 Daumit GL, Pronovost PJ, Anthony CB, Guallar E, Steinwachs DM, Ford DE. Adverse events during medical and surgical hospitalizations for persons with schizophrenia. Arch Gen Psychiatry 2006; 63: 267-72.

40 Mallik S, Krumholz HM, Lin ZQ, Kasl SV, Mattera JA, Roumains SA, et al. Patients with depressive symptoms have lower health status benefits after coronary artery bypass surgery. Circulation 2005; 111: 271-7.

41 Penn DL, Martin J. The stigma of severe mental illness: some potential solutions for a recalcitrant problem. Psychiatric Q 1998; 69: 235-47.

42 Waterreus AJ, Laugharne JD. Screening for the metabolic syndrome in patients receiving antipsychotic treatment: a proposed algorithm. Med J Aust 2009; 190: 185-9.

43 Lambert TJ, Newcomer JW. Are the cardiometabolic complications of schizophrenia still neglected? Barriers to care. Med J Aust. 2009; 190 S39-42.

44 Lévesque LE, Brophy JM, Zhang B. The risk for myocardial infarction with cyclooxygenase-2 inhibitors: a population study of elderly adults. Ann Intern Med 2005; 142: 481-9.

45 Crisanti AS, Love EJ. Mortality among involuntarily admitted psychiatric patients: a survival analysis. SOC Psychiatry Psychiatr Epidemiol. 1999; 34: $627-33$

\section{Psychiatry in the} Old Testament

\section{Did the author of Psalm 30 have cyclothymia or bipolar disorder?}

\section{George Stein}

Psalm 30 is a short psalm used as a song for the dedication of the Temple. It contains a description in religious terminology of two abrupt changes of mood which seem to resemble the mood switches of affective disorder. Examples quoted here are verses 30:3-5 and $30: 8-12$.

30:3 'O Lord, you have brought up my soul from Sheol, restored me to life from among those gone down to the Pit. 4 Sing praises to the Lord, 0 you his faithful ones, and give thanks to his holy name. 5 For his anger is but for a moment: his favour is for a lifetime. Weeping may linger for the night, but joy comes with morning.'

A state of misery is described in verse three (and also in one and two, not quoted here), but an abrupt change of mood seems to occur in the night. The psalm continues:

8 'To you Lord, I cried, and to the Lord I made supplication: 9 What profit is there in my death, if I go down to the Pit? Will the dust praise you? Will it tell of your faithfulness? 10 Hear O Lord and be gracious to me O Lord, be my helper! 11 You have turned my mourning into dancing: you have taken off my sackcloth and clothed me with joy, 12 so that my soul may praise you and not be silent. O Lord my God I will give thanks to you for ever.'

Only a writer who has had personal experience of such an abrupt change of mood, from a state of mourning (depression) to one of joy (elation), could describe it so well. He attributes his improved mood to God whom he thanks. Today, in the clinic, many individuals with affective disorder will report such abrupt mood switches. Those with bipolar I disorder are often too lacking in insight to notice their moods have changed, but people with bipolar II disorder or cyclothymia are all too aware that their mood has improved. Perhaps this author had one of those disorders. 